\title{
Finnish biotechnology - built on solid foundations
}

\section{Committed investment in research infrastructure has laid the foundations for a vibrant biotechnology community in Finland, says Riku Lähteenmälki.}

lthough perhaps better known for its fish, forests and mobile phones, Finland has a substantial presence in biotechnology. The sector has evolved naturally out of a well-established biomedical research base, which has been supported by generous and committed public and private financing. Today, aided by local venture capital, at least five biotechnology clusters have sprung up around Finland. Although the industry is young and predominantly privately owned, this chilly North European country offers a warm hearth for biotechnology start-ups.

\section{REVIVING THE ECONOMY}

Finland is poor in natural resources such as oil, gas and coal, and in the past most of its wealth has come from metal production and machine making, as well as forestry and its associated industries. As a result of a combination of local and global factors - including the demise of the Soviet Union, a key export destination - the Finnish economy went into a nosedive during the 1980s, and the government recognized the need to build a more modern industrial base. As a result, the

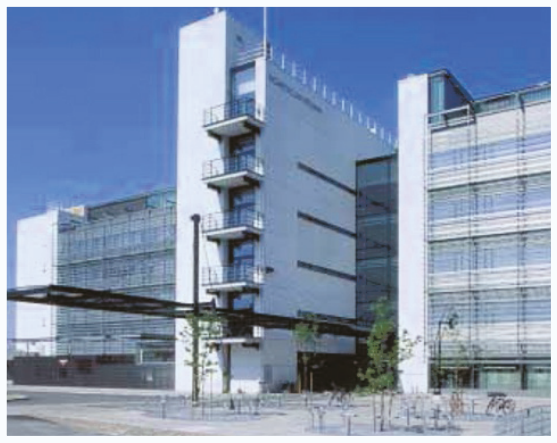

At the hub: Biomedicum Helsinki houses, entirely or in part, six of Finland's Centres of Excellence.

government and local industry jointly supported programmes designed to raise the level of technological know-how in Finland, and biotechnology and information technology were top priorities.

The Finnish government has remained committed to this cause, generously supporting research and development (R\&D). In 2001, $\mathrm{R} \& \mathrm{D}$ spending was about $3.4 \%$ of gross domestic product (GDP), a total of +4.4 billion (US\$3.87 billion) - the second highest (after Sweden) percentage GDP of any country in the world. About $30 \%$ of this investment comes from the public sector and 70\% from the private sector.

Finland also benefits from a receptive climate for biotechnology - most of the country's five million inhabitants have a positive attitude towards technological advances. Companies such as Nokia, the world's leading manufacturer of mobile phones, have set a precedent, demonstrating the potential for

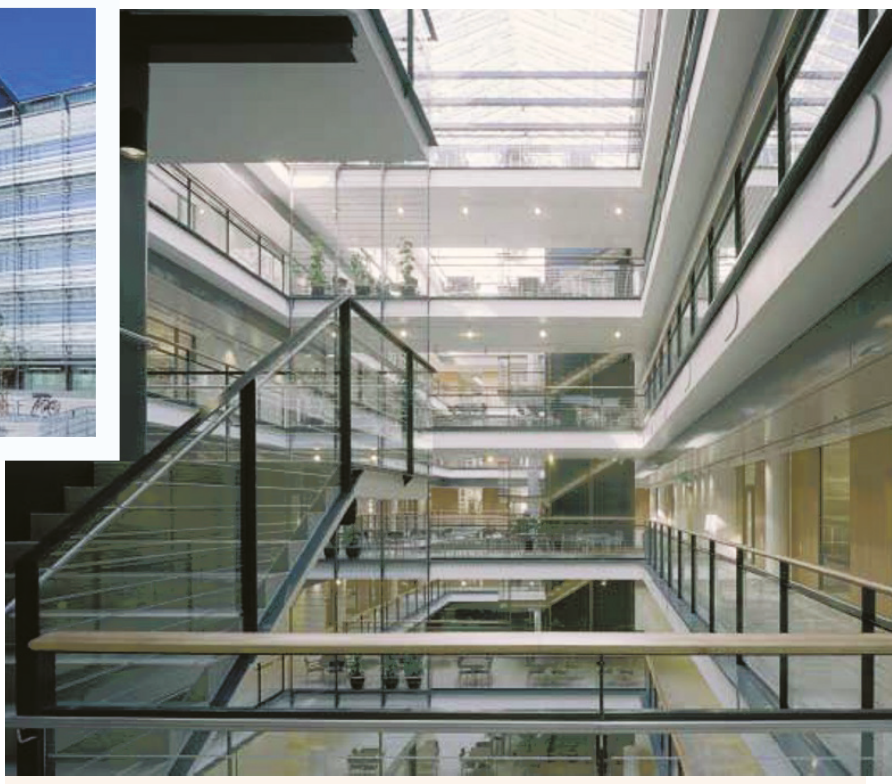

Genes in Helsinki

The Centre of Excellence in Disease Genetics, coordinated by the National Public Health Institute, takes advantage of the unique characteristics of the Finnish population - its geographical isolation, small founding population and excellent healthcare system. The centre hopes to understand the genetics of diseases of the central nervous system, and to identify the genetic component of diseases common in Finland, such as multiple sclerosis, colon cancer and asthma. The Centre of Excellence in Disease Genetics is the largest of the 11 centres focused on biological sciences. All the research is carried out within the Biomedicum Helsinki building, located on the campus of the University of Helsinki next to the University Hospital. Opened in 2001, Biomedicum Helsinki provides a first-class international medical research and training environment, with state-of-the-art facilities for 1,000 researchers and students. The building also hosts, entirely or partially, six Centres of Excellence, several units of the Faculty of Medicine, the Finnish Genome Centre, and various support services. Biomedicum's director Olli Jänne says that although the primary function of the centre is to facilitate basic research and training, it will help to generate a number of companies. Indeed, a business incubator in the vicinity of Biomedicum is being planned. 
rapid growth by Finland's hightechnology sector.

Today, there are over 120 biotechnology companies (including service businesses) in Finland, ranking the country sixth in Europe after the United Kingdom, Germany, France, the Netherlands and Sweden. Finland's strategy is to concentrate on areas in which it has a strong research base pharmaceuticals, diagnostics, biomaterials, functional foods and enzymes.

\section{DRIVE FOR HIGH-TECH}

The rapid rise of Finland's technology sector can be traced back to the national technology programmes put in place by the government during the 1980s. The National

Technology Agency (Tekes) was established in 1983 to coordinate these programmes, which subsequently became the main channels for public funding of technological R\&D in Finland. Tekes operates under the government's Ministry of Trade and Industry and is staffed by 240 industry experts. Tekes' annual budget is about +390 million — roughly $30 \%$ of the total public R\&D expenditure in Finland - of which a third is channelled into life-science research.

Tekes, companies, research institutes, and in some instances the Academy of Finland, jointly plan the technology programmes, which helps to generate cooperation and networking between academia and industry. Each programme typically lasts three to six years, is carried out by several research groups in separate locations, and consists of tens of publicly and privately financed projects. To get funding, companies and research institutions must file project applications with Tekes, which provides $50-60 \%$ of the total costs.

NeoBio, one of the many biomedical programmes, specifically funds biomedical projects with the vision of supporting the development of biotechnology platform technologies and, ultimately, the creation of businesses able to compete internationally.
Launched in October 2001, NeoBio has approved 32 projects, funding them with a total of $\uparrow 50$ million. According to programme coordinator Riikka Heikinheimo, applications from industry are accepted slightly more often than those from academia. NeoBio has a total of 53 projects, when the 11 old Tekes projects and the 10 run by the Ministry of Agriculture and Forestry are included. Projects encompass agricultural biotechnology, industrial biotechnology and cell-based biomanufacturing. Thirteen of the projects are carried out in companies and 40 in research institutions. All the projects are carried out in Finland, but Tekes provides an additional contribution for headhunting top-level researchers from abroad. Heikinheimo says that it is crucial for projects to involve foreign researchers to ensure that they achieve international standards.

Tekes actively encourages the commercialization of innovations resulting from the projects it funds. Applicants are asked whether they have found a partner to which to transfer their technology, or plan to found a business using the intellectual property. If a startup company is planned, Tekes will investigative the project's commercial potential. If the project is deemed viable, Tekes and the Finnish National Fund for Research and Development (Sitra) provide funding through a joint programme called LIKSA, designed to help commercialize innovative projects. Up to $\nmid 35,000$ is given to help the researchers write a formal business plan using the services of a local technology transfer company. To date, LIKSA has financed four business plans within NeoBio.

However, the most significant impact of NeoBio on the Finnish economy in coming years will probably be the generation of intellectual property rather than large numbers of start-ups.

Heikinheimo says: "We do not expect readily commercializable products from the programme, but it will develop know-how and technologies that can be used in product development at a later stage, and every project should yield at least one patent."

In addition to Tekes, $\quad$ A39

\section{Table 1: Selected biomedical companies in Finland}

$\begin{array}{ll}\begin{array}{l}\text { Company } \\ \text { Drug discovery }\end{array} & \text { Focus (Region) } \\ \text { Ark Therapeutics } & \text { Gene-based products to treat cardiovascular disease and cancers (Kuopio) } \\ \text { BioTie Therapies } & \text { Dependence disorders, inflammation, glycobiology (Turku) } \\ \text { FibroGen Europe } & \text { Recombinant human collagen and gelatin (Oulu) } \\ \text { Finncovery } & \text { Drug modelling, prodrugs, cyclodextrins (Kuopio) } \\ \text { FIT Biotech } & \text { DNA vaccines and gene therapies (Tampere) } \\ \text { Galilaeus } & \text { Cancer-drug development and manufacture (Turku) } \\ \text { Hormos Medical } & \text { Hormonal agents to prevent and treat age-related diseases (Turku) } \\ \text { Juvantia Pharma } & \text { Therapies for psychiatric, neurological and vascular diseases (Turku) } \\ \text { MAP Medical } & \text { Radiopharmaceuticals for treating cancer (Kuopio) }\end{array}$

Diagnostics

Biofons

Bio-Nobile

Erilab

HyTest

InnoTrac Diagnostics

Jurilab

Labmaster

Medix Biochemica

Nanobac

SBA Sciences

Biomaterials

Bionx Implants

StickTech

Vivoxid

Enzymes

Finnzymes

Genencor

Roal

Functional foods

Aromtech

Novatreat

Omecol
Diagnostics for intestinal inflammatory and autoimmune diseases (Turku)

In vitro toxicity assays, luminescent biosensors for environmental monitoring (Turku)

Antibodies, analytical services, in vitro diagnostic tests (Kuopio)

Monoclonal antibodies, proteins and enzymes (Turku)

Immunoassay reagents, research reagents (Turku)

DNA chips for diagnostics and drug targeting (Kuopio)

Immunoassays and PCR reagents, enzymes, antibodies (Turku)

Monoclonal antibodies, immunoassays and other chemistry kits (Helsinki)

Immunoassay reagents and kits for detection of nanobacteria (Kuopio)

Diagnostic kits for osteoporosis and bone-metabolism research (Oulu)

Bioabsorbable implants for surgical use (Tampere)

Glass-fibre reinforcement technology (Turku)

Bioactive glass for oral, facial and orthopaedic applications (Turku)

Thermostable DNA polymerases for PCR, enzymes for molecular biology (Helsinki)

Industrial enzymes and special biochemicals (Other)

Industrial enzymes for food, feed, textile and pulp applications (Other) 


\section{HELSINKI}

The University of Helsinki is the largest in Finland and has a long tradition of research in the natural sciences, in particular cancer biology, molecular neuroscience, plant molecular biology and structural virology. The university is now the epicentre of a burgeoning biotech cluster.

In 1995, a new Biocenter building was built just outside the city to facilitate biomedical research. Next to the Biocenter buildings is a 4,000-square-metre business incubator administrated by the Helsinki Science Park, and a new 13,000-squaremetre incubator building is under construction. "We had four companies in the science park in 1996, and there are now 40. Thirty of them originated from the University of Helsinki," says a senior official at the science park. The companies employ about 300 people, and there are 2,000 researchers and technical staff in neighbouring institutions. According to the official, the incubator buildings are owned by both public institutions and private investors. Helsinki Science Park also provides assistance in patenting and licensing, business management, international marketing, finance and training in entrepreneurship. There is an emphasis on education about the development of good manufacturing processes (GMP) and good laboratory processes (GLP) laboratory-quality systems for researchers commercializing biotechnology innovations.

\section{TAMPERE}

Biotechnology in the Tampere region is concentrated in the Finn-Medi Technology Centre, which encompasses the Faculty of Medicine of Tampere University, the Institute of Medical Technology (IMT), biomedical research units of the Technical Research Centre of Finland, the Clinical Trial Centre and several other medical research and education institutions.

More than 1,000 of the 12,000 people who work in the Finn-Medi Technology Centre specialize in biotechnology and medical technology. The technology centre has facilitated the launch of about 40 health-technology and biotechnology companies, including Bionx Implants and FIT Biotech. Tampere's strength has been to combine different biomedical disciplines to develop, for example, novel bioactive implants, says Matti Eskola, managing director of Finn-Medi Research.
Eskola expects new biomaterials companies to emerge in the near future.

On the Finn-Medi site, an 8,000square-metre premises is under construction, with private investors' money, in addition to the existing 25,000 square-metre science park. Other plans for the development of Finn-Medi include establishing a hospital for fitting prostheses, a tissue bank, a laboratory for motion research and a centre for tissue engineering. In 2001, IMT, Tampere University of Technology and the Faculty of Medicine jointly launched a new master of sciences programme in biomedical research and biotechnology, which focuses on bioinformatics and tissue engineering.

\section{KUOPIO}

The development of the Kuopio region arose out of the University of Kuopio's expertise in human health and the environment. Research at the A. I. Virtanen Institute - named after Artturi Virtanen, who won a Nobel prize for his animal-fodder preservation technology has gained worldwide recognition in the fields of animal and plant biotechnology, molecular medicine, neurosciences, drug design and food biotechnology.

When healthcare technology is included, the Kuopio region can boast of 58 life-science companies, employing 850 people out of the 3,000 in the region working in biomedical fields.

The Teknia high-technology buildings provide 55,000 square metres of space, of which 20,000 square metres are dedicated to biotechnology and house companies, research units and a state-of-the-art biotechnology production unit with GMPgrade animal cell and microbial bioreactor laboratories. Mediteknia is a new 8,000square-metre research centre, which will be financed mainly by the government, the European Union and the city of Kuopio at a cost of $\dagger 14$ million. It will comprise a Drug Research and Development Centre, a Clinical Research Centre, and a Food and Health Research Centre. Mediteknia is projected to increase collaboration between the university drug-research groups and the pharmaceutical industry and to transfer new products and technologies to the private sector. Kuopio's objective is to combine R\&D on human health, nutrition and the environment, covering the entire food chain from 'farm to fork', as well as the drug-development process from target identification to clinical research.

\section{OULU}

Founded in 1986, Biocenter Oulu was Finland's first biotechnology research institute. The Biocenter is a virtual organization, networking the bioscience, medicine and process-technology faculties of the University of Oulu. Biocenter Oulu has been used as a model unit for the Finnish Centre of Excellence Programme, and has spun out more than ten biotech companies, many originating from local collagen research. The city of Oulu has invested about @ 10 million in a pilot manufacturing plant built to GMP standards, which allows researchers to move research into production. Next to the pilot factory is Oulu University Hospital, and the Medipolis incubator building, currently hosting some 40 companies. In addition, a joint programme called BioOulu, run by the electronics and biotech units of the Technical Research Centre of Finland and the University of Oulu, is about to establish a biosensor research unit in Oulu. The unit is one of the spearhead projects of Bioforum, founded this year by local players such as the Biocenter, to improve collaboration inside the biocluster and between different technology sectors.

\section{TURKU}

About half of Finland's pharmaceutical and diagnostics companies are located in Turku, and around 300 patented inventions in pharmaceuticals and diagnostics have originated from the Turku region. The BioTurku community consists of three universities, a polytechnic, some 30 biotechnology companies, and more than 600 bioscience researchers. The BioCity and PharmaCity buildings, which are located close to the university campuses and the Turku University Hospital, have a total 55,000 square metres of floor space and house, in addition to the

biotechnology companies, the Centre for Biotechnology, Centre for Biomaterials, the pharmaceutical biotechnology unit of the Technical Research Centre of Finland, the Functional Foods Forum, a business incubator and other service organizations. According to Tapio Hurme, manager of the incubator, the aim is to launch $\mathbf{5 0}$ new biotechnology companies by the year 2010 . The city of Turku has invested +14 million and has zoned 113,000 square metres to permit the construction of biotechnology production facilities in the nearby Turku BioValley area. 
the Academy of Finland implements public financing of innovation in the country. The academy's goal is to improve the quality and reputation of basic research in Finland to maintain a competitive pipeline of innovations that can be commercialized in the future.

\section{BUILDING ON BASICS}

The academy receives $\nmid 160$ million in annual funding about $12 \%$ of total public R\&D spending in Finland. Life sciences received +40 million funding during 1999, and funding has been growing at about $20-30 \%$ per year for the past three years. About $85 \%$ of the academy's funding is directed to academic research. For example, the Life 2000 programme, financed to the tune of +14 million during 2000-03, consists of 89 research teams working on a total of 39 projects in neuroscience, developmental biology, functional genomics, biophysics, bioinformatics, and the ethical, legal and sociocultural aspects of bioscience research. Tekes is involved in the planning of the programme and finances two of the projects.

Programme coordinator Mika Tirronen says that the programme is a response by the academy to the needs of Finland's life-science sector. Tirronen says that initiatives for a programme come from the grass roots - from academic and industrial researchers - and those science council members responsible for planning the programme are active researchers themselves. Individual projects for a programme are selected on a competitive basis with the help of tens of Finnish and foreign experts, who give statements on applications.

The Academy of Finland also runs a Centres of Excellence programme designed to develop creative research and training environments by supporting the development of multidisciplinary research units that can become internationally competitive. Eleven of the 26 Centres of Excellence nominated by the academy are biotechnology-related (see "Genes in Helsinki", page A35). The units have an average of 50 staff members apiece and work on a variety of projects, including research into cellsurface receptors, the genetics of disease, collagen, forest biotechnology, cancer biology, structural virology, biomaterials and tissue engineering. Funding for the centres comes not only from the academy but also from universities, research institutes, Tekes, government ministries, companies and foundations.

For the past eight years, the government has also invested heavily in regional development, in part through the Centres of Expertise programme. Whereas the Centres of Excellence programme funds research regardless of its location, the Centres of Expertise programme seeks to create a favourable infrastructure for business on a regional level, providing infrastructure and services to enable commercialization of research innovations.

\section{TEAMING UP}

One function of the programme is to generate team spirit within the regions, promote regional strengths, and thereby improve companies' competitiveness. Industry, local governments, universities, polytechnics, research institutes and other branches of public administration in each region are brought together to decide on future investments. Five regions are active in biotechnology - Helsinki, Turku, Tampere, Kuopio and Oulu (see "Finland's biotechnology clusters", page A37). Local technology centres run the programme, which receives a total annual funding of +200 million from the national government and local players including government, companies, universities and other investors.

Finnish biotechnology has clearly benefited from a

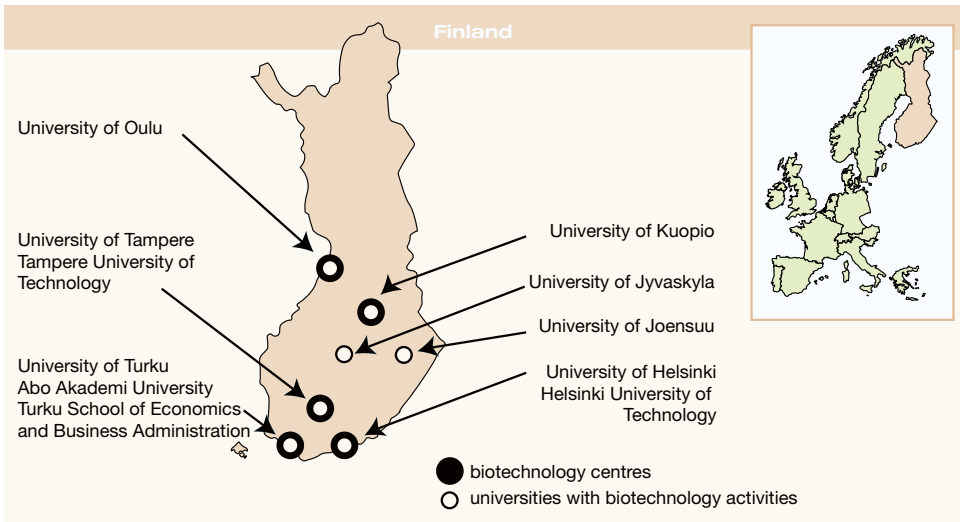

generous support of its basicresearch infrastructure by the government, the European Union, and private foundations and companies, but researchers continue to experience problems in translating success at the bench into viable business opportunities. In particular, academic researchers have difficulty raising funding for the very early stages of starting up a company. To ease this process, Tekes provides up to $\$ 13,000$ for market research about a potential invention information essential for a winning business plan — in addition to the aforementioned LIKSA grants available for writing business plans.

Another problem is the shortage of skilled management, in particular managers experienced in product development and business strategy within life sciences. With only a limited local pharmaceutical industry, Finland may have trouble filling posts with qualified professionals. Fortunately, at least for now, the supply of graduates is meeting the needs of the industry.

Almost all start-up funding for biotechnology companies in Finland comes from venture capital. About $95 \%$ of venture capital comes from domestic companies, predominantly BioFund and Sitra, although many smaller local venturecapital funds exist. Although BioFund now invests internationally, it has a portfolio of +180 million, half of which is invested in Finland. Sitra, a venture-capital organization working under the mandate of the Finnish parliament, invests †70 million in financing Finnish biotechnology start-ups.

But Matti Eskola of the technology centre Finn-Medi Research says that the financing of the commercialization process should be more streamlined, so that pre-seed, seed and venture capital are available for a starting enterprise. After the initial phase, getting finance is easier. Good companies can always raise money from the venturecapital market, says Seppo Mäkinen of BioFund.

For now, biotechnology in Finland is young and overwhelmingly privately owned. Only two companies have gone public: Bionx Implants, which makes surgical implants, is listed on the Nasdaq exchange, and BioTie Therapies is listed on the Helsinki Stock Exchange. Fibrogen Europe, a developer of collagen-based products with a US parent company (FibroGen, South San Francisco, California), will most likely be the next to go public, probably on the Helsinki Stock Exchange. Recently, Ark Therapeutics, which has a parent company in London, announced its intention to list on the London Stock Exchange. But several firms have products on or close to the market, and Finnish biotechnology seems determined to make Scandinavian biotechnology into one of Europe's hot topics. Rilku Lähteenmäki is a freelance writter based in Turku, Finland. e-mail: riku.lahteenmaki@netti,fi 